NASA Technical Memorandum 107257

AIAA-96-2762

\title{
Flow Coupling Effects in Jet-In-Crossflow Flowfields
}

D.B. Bain and C.E. Smith

CFD Research Corporation

Huntsville, Alabama

D.S. Liscinsky

United Technologies Center

East Hartford, Connecticut

J.D. Holdeman

Lewis Research Center

Cleveland, Ohio

Prepared for the

32nd Joint Propulsion Conference

cosponsored by AIAA, ASME, SAE, and ASEE

Lake Buena Vista, Florida, July 1-3, 1996

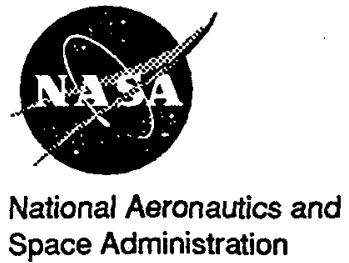




\title{
FLOW COUPLING EFFECTS IN JET-IN-CROSSFLOW FLOWFIELDS
}

\author{
D.B. Bain \\ C.E. Smith \\ CFD Research Corporation \\ Huntsville, Alabama \\ D.S. Liscinsky \\ United Technologies Center \\ East Hartford, Connecticut \\ J.D. Holdeman \\ NASA Lewis Research Center \\ Cleveland, Ohio
}

\begin{abstract}
$\underline{\text { Abstract }}$
The combustor designer is typically required to design liner orifices that effectively mix air jets with crossflow effluent. CFD combustor analysis is typically used in the design process; however the jets are usually assumed to enter the combustor with a uniform velocity and turbulence profile. The jet-mainstream flow coupling is usually neglected because of the computational expense. This CFD study was performed to understand the effect of jet-mainstream flow coupling, and to assess the accuracy of jet boundary conditions that are commonly used in combustor internal calculations.

A case representative of a plenum-fed quick-mix section of a Rich Burn/Quick Mix/Lean Burn combustor (i.e. a jet-mainstream mass-flow ratio of about 3 and a jetmainstream momentum-flux ratio of about 30 ) was investigated. This case showed that the jet velocity entering the combustor was very non-uniform, with a low normal velocity at the leading edge of the orifice and a high normal velocity at the trailing edge of the orifice. Three different combustor-only cases were analyzed with uniform inlet jet profile. None of the cases matched the plenum-fed calculations. To assess liner thickness effects, a thin-walled case was also analyzed. The CFD analysis showed the thin-walled jets had more penetration than the thick-walled jets.
\end{abstract}

\section{Nomenclature}

A $_{\text {orifice }}$ Geometric Area of Orifice

A tot Total Flow Area in Each Axial Plane

$A_{i} \quad$ Flow Area of Cell i

$\begin{array}{ll}\mathrm{C}_{\mathrm{avg}} & \mathrm{m}_{\mathrm{j}} /\left(\mathrm{m}_{\mathrm{j}}+\mathrm{m}_{\infty}\right)=\theta_{\mathrm{EB}} \\ \mathrm{C}_{\mathrm{i}} & \text { Jet Mass Fraction in Cell } \mathrm{i} \\ \mathrm{c}_{\mathrm{var}} & \left(\mathrm{l} / \mathrm{A}_{\mathrm{TOT}}\right) \sum_{\mathrm{i}} \mathrm{A}_{\mathrm{i}}\left(\mathrm{C}_{\mathrm{i}}-\mathrm{C}_{\mathrm{avg}}\right)^{2} \\ \mathrm{DR} & \text { Density Ratio } \mathrm{p}_{\mathrm{j}} / \mathrm{\rho}_{\infty} \\ \mathrm{f} & \text { Mixture Fraction } \\ \mathrm{h} & \text { Enthalpy } \\ \mathrm{H} & \text { Duct Height } \\ \mathrm{J} & \text { Momentum-Flux Ratio }\left(\mathrm{\rho}_{\mathrm{j}} \mathrm{V}_{\mathrm{j}}^{2}\right) /\left(\mathrm{\rho}_{\infty} \mathrm{U}_{\infty}^{2}\right) \\ \mathrm{k}_{\infty} & \text { Turbulent Kinetic Energy of Mainstream } \\ \mathrm{m}_{\mathrm{j}} & \text { Mass-Flow of Jets } \\ \mathrm{MR} & \text { Mass-Flow Ratio } \mathrm{m}_{\mathrm{j}} / \mathrm{m}_{\infty} \\ \mathrm{m}_{\infty} & \text { Mass-Flow of Mainstream } \\ \mathrm{P} & \left.\text { Static Pressure (N/m }{ }^{2}\right) \\ \mathrm{P}_{\text {exit }} & \text { Static Pressure at Combustor Exit } \\ \mathrm{P}_{\mathrm{jet}} & \text { Static Pressure of Jet } \\ \mathrm{P}_{\mathrm{s}_{1}} & \text { Static Pressure Upstream of } \text { Quick-Mix } \\ & \text { Orifices } \\ \mathrm{P}_{\mathrm{t}} & \text { Total Pressure at Plenum Entrance } \\ \mathrm{P}_{\infty} & \text { Static Pressure of Mainstream } \\ \mathrm{T} & \text { Temperature (K) } \\ \mathrm{T}_{\text {exit }} & \text { Exit Temperature } \\ \mathrm{T}_{\mathrm{jet}} & \text { Temperature of Jet } \\ \mathrm{T}_{\infty} & \text { Temperature of Mainstream } \\ \mathrm{U}_{\infty} & \text { Mainstream Flow Velocity (m/s) } \\ \mathrm{V}_{\mathrm{j}} & \text { Jet Velocity (m/s) } \\ \mathrm{x} & \text { Axial Coordinate, } \mathrm{x}=0 \text { at leading edge of the } \\ \mathrm{x} / \mathrm{H} & \text { orifice } \\ \mathrm{y} & \text { Axial Distance-to-Duct Height Ratio } \\ & \text { Vertical Coordinate } \\ & \end{array}$

1

Copyright 1996 by American Institute of Aeronautics and Astronautics, Inc. No copyright is asserted in the United States under Title 17, U.S. Code. The U.S. Government has a royalty-fee license to exercise all rights under the copyright claimed herein for Governmental purposes. All other rights are reserved by the copyright owner. 


$\begin{array}{ll}z & \text { Lateral Coordinate } \\ \varepsilon_{\infty} & \text { Turbulent Energy Dissipation of Mainstream } \\ \phi_{\mathrm{rb}} & \text { Rich-Burn Equivalence Ratio } \\ \phi_{\mathrm{lb}} & \text { Lean-Burn Equivalence Ratio } \\ \rho_{\mathrm{jet}} & \text { Density of Jet } \\ \rho_{\infty} & \text { Density of Mainstream }\end{array}$

\section{Introduction}

The mixing of jets with mainstream flow is very significant in many gas turbine combustor applications. In conventional combustor design, air is injected through primary and dilution orifices to mix with hot gas effluent. The design of the orifices is important in combustor performance and durability (i.e. exit temperature pattern factor, exit radial temperature profile, combustion efficiency, emissions, liner hot streaks, etc.). Dilution jet mixing has received a lot of attention as discussed by Holdeman 1 . More recently, jet mixing has drawn a lot of attention in regards to low emission combustor design, especially the Rich Burn/ Quick Mix/Lean Burn (RQL) ${ }^{2}$ combustor design. The RQL combustor requires a large amount of bypass air (typically a jet-to-mainstream mass-flow ratio of 3 ) to be efficiently mixed with rich burn effluent so that $\mathrm{NO}_{\mathrm{x}}$ emissions are kept to a minimum. 3 The optimization of this type of mixing process has received a lot of study, ${ }^{4-16}$

CFD analysis is typically used to help design the orifice pattern for effective mixing. To conserve computer resources, CFD analysis is usually performed on the interior of the combustor; the inlet boundary conditions for the air jets are specified by the designer. The jets are typically input with uniform velocity and turbulence levels, and the flow direction is determined by $1 D$ annulus models. Usually, an effective orifice flow area is modeled, corresponding to the geometric area multiplied by the discharge coefficient. Other research 17 21 has shown that there is a coupling effect between the annulus airflow and combustor interior flow, and the prediction of jet penetration and mixing is strongly affected by including the annulus flow in the CFD analysis. Indeed, in the next five years as parallel computers are utilized, CFD analysis will be performed starting from the compressor exit and going all the way to the combustor exit. But, for now, only the interior of the combustor is usually analyzed, and ways of defining the jet boundary conditions are needed.
McGuirk's $20-21$ work focussed on primary and dilution hole airflows that had jet-to-mainstream mass-flow ratios less than 0.5 . This paper studies mass-flow ratios more commonly used in RQL combustors. Instead of annulus flow, the air jets are fed by a plenum as a first step in understanding the coupling effect between jet and mainstream. A baseline plenum case is discussed first, and the nonuniformity of the jet exiting the orifice is presented. The CFD analysis is then verified by comparing isothermal numerical predictions with experimental measurements. Next, three cases of the combustor interior are analyzed to try and identify ways to specify jet boundary conditions that capture the flow coupling effects. And last, a thin-walled liner case is compared to a thick-walled liner case to assess the differences in flow coupling.

\section{CFD Code}

The approach in this study was to perform 3-D numerical calculations on generic combustor geometries with and without the addition of plenums. The code named CFD-ACE 22 was used to perform all of the computations. The basic capabilities/methodologies in CFD-ACE include:

(1) co-located, fully implicit and strongly conservative finite volume formulation;

(2) solution of two-and three-dimensional NavierStokes equations for incompressible and compressible flows;

(3) non-orthogonal curvilinear coordinates;

(4) multi-block grid topology;

(5) upwind, central (with damping), second order upwind and Osher-Chakravarthy differencing schemes;

(6) standard 23 , extended, RNG 24 and low Reynolds number ${ }^{25} \mathrm{k}-\varepsilon$ turbulence models;

(7) instantaneous, one-step, two-step, and four-step heat release and emission combustion models;

(8) spray models including trajectory, vaporization, etc.; and 
(9) pressure-based solution algorithms including SIMPLE and a variant of SIMPLEC.

\section{Details Of Numerical Calculations}

The focus of this study was to analyze the flow coupling effect that can occur in jet-in-crossflow geometries. The baseline configuration, shown in Figure 1, can be described as having an annular quickmix zone section with orifices located on both the inner and outer diameter liner. The orifices are fed by plenums. The orifice length-to-diameter ratio, $L / d$, was greater than one, representative of a thick-walled combustor. The inner radius of the quick-mix zone annulus measured $0.3896 \mathrm{~m}$ and the outer radius measuring $0.4404 \mathrm{~m}$. The height of the quick-mix zone was $0.0508 \mathrm{~m}$. The axial length of the calculation extended $0.152 \mathrm{~m}$ from the leading edge of the orifice $(x / H=3.0)$. The walls (i.e. thickness of the orifices) were modeled as being $0.0064 \mathrm{~m}$ thick. Each orifice was fed by a plenum that was $0.065 \mathrm{~m}$ in length and $0.076 \mathrm{~m}$ in height. The orifices were slots with semi-circular ends and had 2:1 length-to-width aspect ratios.

To enhance the computational efficiency of the numerical calculations, only one set of orifices (top and bottom) were modeled. The orifices were located on the inner and outer diameter in the same axial plane, and inline in the transverse direction. The transverse calculation domain extended from midplane to midplane between the jets' centerline. The included angle was 3.75 degrees. Periodic boundary conditions were assumed on the transverse boundaries.

For the combustor-only calculations only the quick-mix zone was used. The quick-mix orifices were modeled as inlets with a uniform velocity profile. The velocity magnitude was determined via three different methods (Figure 2). The first method used the velocity calculated from the plenum to mixer exit pressure drop. The second method determined the pressure drop by using the total pressure in the plenum and the average static pressure across the quick-mix zone. The third method calculated a velocity based on the mass-flow through the geometric area of the orifice. The jet velocities for the three method were calculated to be; $155 \mathrm{~m} / \mathrm{sec}, 135 \mathrm{~m} / \mathrm{sec}$, and $92 \mathrm{~m} / \mathrm{sec}$ respectively.

To assess the effects of orifice thickness, a thin-walled geometry was also analyzed. The thin-walled case was identical to the baseline case except for the orifice thickness. For the thin-walled geometry the wall thickness was reduced to be $0.000889 \mathrm{~m}$.

The flow conditions of the mainstream and the jets were:

$$
\begin{gathered}
\text { Mainstream } \\
\begin{array}{l}
\text { Jets } \\
\mathrm{U}_{\infty}=43.5 \mathrm{~m} / \mathrm{s} \quad \mathrm{P}_{\text {jet }}=1.03 \times 10^{6} \mathrm{~N} / \mathrm{m}^{2} \\
\mathrm{~T}_{\infty}=2035 \mathrm{~K} \quad \mathrm{~T}_{\text {jet }}=777 \mathrm{~K} \\
\mathrm{P}_{\infty}=9.72 \times 10^{5} \mathrm{~N} / \mathrm{m}^{2} \\
\mathrm{k}_{\infty}=118.0 \mathrm{~m}^{2} / \mathrm{sec}^{2} \\
\varepsilon_{\infty}=5.4 \times 10^{4} \mathrm{~m}^{2} / \mathrm{sec}^{3} \\
M R=3.20 \\
\mathrm{DR}=3.20 \\
\mathrm{~T}_{\text {exit }}=1755 \mathrm{~K} \\
\phi_{\mathrm{rb}}=2.0 \\
\phi_{\mathrm{lb}}=0.425
\end{array}
\end{gathered}
$$

\section{Grids}

The computational mesh was created using CFDGEOM $^{26}$, an interactive three-dimensional geometry modeling and mesh generation software. The baseline case consisted of approximately 86,500 cells. The grid shown in Figure 1 was created with 5 domains. Each plenum was modeled as a domain as well as each orifice. The quick-mix zone was also specified as a domain and was composed of 28,329 cells, 71 cells in the axial direction $(x), 19$ cells in the vertical direction (y), and 21 cells in the transverse direction (z). The plenum grid was distributed as $42 \times 29 \times 21$ cells ( $x, y, z$, direction). The 2:1 slots were composed of $28 \times 11$ uniformly distributed cells, with 7 cells in the vertical direction to represent the combustor wall thickness $(0.0064 \mathrm{~m})$. The grid upstream and downstream of the slots was expanded/contracted so that each cell adjacent to the slot matched the cell size in the interior of the slot. The cells in the vertical direction were compressed in the wall regions to more accurately capture wall effects.

For the combustor-only case a single domain mesh consisting of solely the quick-mix section was used. Finally, the thin-walled case was the same as the baseline case except the thickness of the orifices was reduced.

3

American Institute of Aeronautics and Astronautics 


\section{Numerics \& Models}

The following conservation equations were solved: $u$ momentum, $\mathrm{v}$ momentum, $\mathrm{w}$ momentum, mass (pressure correction), turbulent kinetic energy (k), turbulent energy dissipation $(\varepsilon)$, and mixture fraction (f). The convective fluxes were calculated using upwind differencing, and the diffusive fluxes were calculated using central differencing. The standard $k-\varepsilon$ turbulence model was employed and conventional wall functions were used. The walls were assumed to be adiabatic. The turbulent Schmidt and Prandtl numbers were set to be 0.5. A fast chemistry (instantaneous) model was assumed. Equilibrium products were also assumed. The inlet to the rich-burn section was assumed to be the equilibrium products of a fully-burned 1.8 equivalence ratio. The fuel used was $\mathrm{C}_{10} \mathrm{H}_{19}$, representative of Jet A fuel.

\section{Convergence}

All error residuals were reduced at least 6 orders of magnitude, and continuity was conserved in each axial plane to the fifth decimal. A converged solution required approximately 5-7 CPU hours on a IBM RS6000 Model 560 computer. Although the cases reported in this paper were performed using the IBM RS6000, additional cases were run using the NAS C-90 computer.

\section{Results and Discussion}

\section{Baseline Plenum-Fed Case}

Figure 3 shows the temperature contours for the baseline plenum-fed case. The temperature contours are plotted in a lateral plane through the orifice centerline. The jets show near optimum jet penetration, penetrating to approximately $1 / 4$ duct height. There is a slight difference in penetration between the outer diameter and inner diameter jets; this difference is caused by geometric differences. The coupling effect causes a nonuniformity of the jet flowfield as it exits the orifice. By examining the velocity vectors and profile at the orifice exit (Figure 4), the jet velocity non-uniformity in the jet flowfield can be seen. Because of the large L/d of the orifice, the jet velocity is essentially normal to the crossflow. A low normal velocity at the leading edge of the orifice and a high normal velocity at the trailing edge is evident.
Similarly, the static and total pressure at the orifice discharge was also non-uniform as seen in Figure 5 and 6. There is a high total pressure core in the center of the orifice, but at the edges of the orifice there is a total pressure loss. The non-uniform static pressure is further illustrated in the axial static pressure plot presented in Figure 7. The static pressure varies from $30,000 \mathrm{~N} / \mathrm{m}^{2}$ above combustor exit pressure to $-15,000$ $\mathrm{N} / \mathrm{m}^{2}$ below the combustor exit pressure.

\section{Non-Reacting Validation Case}

To validate the plenum-fed baseline case, it was decided to perform a thick-orifice isothermal case for which jet mixing data existed. The case selected is described below, with the comparison between numerical predications and experimental measurements.

\section{Geometry}

For the validation case, the geometry consisted of a cylindrical mixing zone with 8 round holes uniformly spaced on the can circumference. Figure 8 shows a schematic of the test geometry. The diameter of each hole was $0.0178 \mathrm{~m}(0.7$ inches) and diameter of the can was $0.0792 \mathrm{~m}$ ( 3.88 inches). The thickness of each round hole was $0.0792 \mathrm{~m}$ ( 3.12 inches). Figure 8 shows the plenum which is approximately $0.529 \mathrm{~m}$ ( 6 inches) in length. The mainstream flow enters from an inlet section $0.3048 \mathrm{~m}$ long and $0.079 \mathrm{~m}$ in diameter. The inlet section had a divergence angle of 2 degrees with an initial diameter of $0.079 \mathrm{~m}$ that diverges to the mixing section diameter of $0.0986 \mathrm{~m}$. The orifices are located $0.0508 \mathrm{~m}$ downstream of the bulkhead that connects the mainstream inlet feed into the quick-mix region. The experimental procedure is described in, for example, Reference 14.

The computational grid is shown in Figure 9. To enhance the computational efficiency of the numerical calculations, only one orifice was modeled (45 deg. sector) and periodic boundaries were assumed. The grid was separated into three distinct blocks. The first block represented the quick-mix zone, consisting of 78 cells in the axial direction $(x), 19$ cells in the vertical direction (y), and 29 cells in the transverse (z) direction. The second block was the plenum; it was composed of $11 \mathrm{x}$ $14 \times 11$ cells $(x, y, z)$. The third block represented the orifice, composed of $29 \times 29$ uniformly distributed cells. The orifice was modeled with 14 cells in the 
vertical direction to represent the thickness of the combustor wall. In the quick-mix section, the grid upstream and downstream of the orifice region was expanded/contracted so that each cell adjacent to the orifice region matched the cell size in the slot region. The cells in the vertical direction were compressed in the vicinity of the wall to more accurately capture wall effects.

\section{Flow Conditions}

The flow conditions of the mainstream and jets were specified to be:

$$
\begin{array}{ll}
\text { Mainstream } & \text { Jets } \\
\mathrm{U}_{\infty}=4.637 \mathrm{~m} / \mathrm{s} & \mathrm{P}_{\text {jet }}=106,166 \mathrm{~N} / \mathrm{m}^{2} \\
\mathrm{~T}_{\infty}=291.67 \mathrm{~K} \quad \mathrm{~T}_{\text {jet }}=291.67 \mathrm{~K} \\
\mathrm{P}_{\infty}=101,341 \mathrm{~N} / \mathrm{m}^{2} \\
\mathrm{k}_{\infty}=2.9027 \times 10^{-2} \mathrm{~m}^{2} / \mathrm{sec}^{2} \\
\varepsilon_{\infty}=3.2063 \times 10^{-1} \mathrm{~m}^{2} / \mathrm{sec}^{3}
\end{array}
$$

The mass-flow ratio was specified to be 1.0 corresponding to a momentum-flux ratio of 30 .

\section{Validation Case Results}

Shown in Figure 10 are the jet mixture fraction axial slices measurements. The comparable numerical results are also presented in Figure 10. Axial slices were extracted at $x / R$ locations of $1.28,1.54$, and 2.05 downstream of the leading edge of the round hole. The same color bar was used for the calculated results and experimental measurements. The numerical results show very good agreement with the experimental results at all of the downstream stations. At the closest station $(x / R=1.28)$, the computational results capture the center mainstream core along with the slight bluish contour levels present at about mid-radius. Moving to the farther downstream locations, the numerical results show a slightly slower mixing rate than seen in the experimental results.

Figure 11 shows the spatial unmixedness curves for the CFD and experimental results. Planar unmixedness, $U_{s}, 27$ is a parameter that quantifies the unmixedness of a distribution and can be defined as:
Good overall agreement can be seen. Thus, from an engineering viewpoint, the plenum-fed calculations capture the overall characteristics of the jets-incrossflow.

\section{Combustor-Only Calculations}

Shown in Figure 12 are the results of the combustoronly calculations for three specified uniform inlet velocities: 1) jet velocity corresponding to the overall pressure drop velocity, $155 \mathrm{~m} / \mathrm{sec}$; 2) jet velocity corresponding to the average pressure drop velocity, 135 $\mathrm{m} / \mathrm{sec}$; and 3 ) jet velocity corresponding to the massflow through the orifice geometric area, $92 \mathrm{~m} / \mathrm{sec}$. Compared to the baseline calculation (Figure 3), each combustor-only case predicted jet overpenetration. The highest jet velocity produced the greatest amount of overpenetration, as evidenced by the mainstream flow being deflected to the outer wall. This is illustrated by the hotter temperatures near the ID and OD walls. The results of the lowest jet velocity (Method 3) still predicted overpenetrating jets, but gave the closest overall agreement to the baseline case results. Note that the OD near wall temperatures are hotter than the ID temperature for each case. This occurs because the office spacing is greater for the OD wall, resulting in more mainstream flow passing between the jets.

Thus it appears that there is no simple way to capture the flow coupling that occurs with plenum-fed flowfields. As discussed previously for the baseline plenum geometry, there exists non-uniformity in the jet flow at the discharge orifice plane. In order to use an inlet boundary condition for the orifice, one would have to devise a way to determine the velocity profile that correctly produces the flow non-uniformity at the orifice discharge. This includes correctly modeling the nonuniform velocity profile, turbulence quantities, and the flow angle. The determination of these factors creates potential problems because of their variation across the orifice cross-sectional area. If it was possible to ascertain an acceptable method of capturing the flow non-uniformity, there is no guarantee that this method would be generally applicable to a variety of different orifices (i.e. round holes, slanted slots, etc...,). Therefore from a design standpoint, it probably would be very difficult to accurately capture the jet coupling effect without the use of the plenums.

$$
U_{\mathrm{s}}=\mathrm{c}_{\mathrm{var}} /\left[\mathrm{c}_{\mathrm{avg}}\left(1-\mathrm{c}_{\mathrm{avg}}\right)\right]
$$




\section{Effect of Wall Thickness}

For completeness, analysis was performed on a thinwalled liner to asses the effect of wall thickness on the flow coupling effect. Presented in Figure 13 are the temperature contour results of the thin-walled case. Compared to the thick-walled case (Figure 3), the thinwalled geometry showed higher jet penetration and higher overall downstream mixing.

Based on the work performed by Lichtarowicz, Duggins, and Markland 28, the discharge coefficient for orifices with length/diameter ratios (L/d) between 0 and 1 vary significantly as a function of $\mathrm{L} / \mathrm{d}$. From these results, it would be safe to assume that the thin-walled configuration ( $\mathrm{L} / \mathrm{d}=0.04$ ) would have a smaller discharge coefficient than the thick-walled design $(\mathrm{L} / \mathrm{d}>$ 1). The lower $\mathrm{Cd}$ in the thin-walled case would then result in an increased pressure drop across the orifice for the same mass-flow ratio. The total pressure variation for the two geometries is presented in Figure 14. The pressure drop, plenum total pressure-combustor total pressure, for the thin-walled case is about $6.5 \%$ whereas the thick-walled case has a pressure drop around $5.8 \%$. Despite the variation in $\mathrm{Cd}$, the normal velocity levels were essentially the same for both cases. The comparable normal velocity levels for both the thin and thick-walled cases are shown in Figure 15. The differences in the penetration levels for the thick and thin-walled cases can be addressed by examining the velocity profiles. The velocity flowfield for both cases exhibit similar characteristics, but one significant difference seen is that the velocity profiles for the thinwalled case are pushed farther into the mainstream flow. This inboard translation of the velocity profiles results in more jet penetration into the quick-mix zone for the thin-walled case. Thus the increased jet penetration can be directly attributed to the lower discharge coefficient and subsequently the higher pressure drop evident in the thin-walled case. The importance of modeling the flow through the orifice is thereby shown.

\section{Conclusions}

CFD analyses were performed on air jets injected into rich-burn effluent flowing in an annulus. Jet-tomainstream mass-flow ratios $(-3)$ typical of $R Q L$ combustors were analyzed. Two types of calculations were performed: 1) only the combustor was modeled, with the jet flow specified at the orifice discharge plane, and 2) the jet plenum and orifice were included in the calculation domain. Results from the CFD analysis showed:

1) There exists a strong coupling between the jet flow and mainstream flow evidenced by the large velocity profile at the orifice exit.

2) This coupling effect could not be easily captured by specifying commonly-used uniform jet velocity boundary conditions for combustor-only CFD calculations.

3) The only way to accurately predict jet-in-crossflow flowfields is to include both the interior and exterior (plenums) flowfields in the CFD analysis. To do this, an order of magnitude increase in the number of computational cells is needed over conventional computational grid sizes.

4) CFD analysis was able to capture the effect of liner thickness on jet penetration and mixing, provided the calculation domain included the external and internal combustor geometry.

\section{Acknowledgements}

This work was supported by NASA Contract NAS325967, and NAS computer time was provided by NASA Lewis Research Center. The authors would like to thank the CFDRC software development and support staff for implementing improvements to the software. In addition thanks are given to Ms. Marni Kent for preparing this typescript.

\section{References}

1. J. D. Holdeman, "Mixing of Multiple Jets with a Confined Subsonic Crossflow," Progress in Energy and Combustion Sciences, Vol. 19, pp. 31-70, 1993. (See also NASA TM 104412, 1991 and AIAA 91-2458, 1991.)

2. R. J. Shaw, "Engine Technology Challenges for a 21 st Century High Speed Civil Transport," AIAA Tenth International Symposium on Air Breathing Engines, September 1-6, 1991 (Also NASA TM 104363). 
3. S. A. Mosier and R. M. Pierce, "Advanced Combustion Systems for Stationary Gas Turbine Engines," Vol. 1, EPA Contract 68-02-2136, 1980.

4. J. D. Holdeman, D. S. Liscinsky, V. L. Oechsle, G. S. Samuelsen, and C. E. Smith, "Mixing of Multiple Jets with a Confined Subsonic Crossflow in a Cylindrical Duct," Accepted for publication in Journal of Engineering for Gas Turbines and Power, 1996 (Also ASME Paper-GT-482 \& NASA TM 107185).

5. C. E. Smith, M. V. Talpallikar, and J. D. Holdeman, "A CFD Study of Jet Mixing in Reduced Flow Areas for Lower Combustor Emissions," AIAA 91-2460, June 1991 (Also NASA TM 104411).

6. D. B. Bain, C. E. Smith, and J. D. Holdeman, "CFD Mixing Analysis of Jets Injected from Straight and Slanted Slots into Confined Crossflow in Rectangular Ducts," AIAA 92-3087, June 1992 (Also NASA TM 105699).

7. D. S. Liscinsky, B. True, A. Vranos, and J. D. Holdeman, "Experimental Study of Cross-Stream Mixing in a Rectangular Duct," AIAA 92-3090, June 1992 (Also NASA TM 106194).

8. D. S. Liscinsky, A. Vranos, and R. P. Lohmann, "Experimental Study of Crossflow Mixing in Cylindrical and Rectangular Ducts," NASA CR 187141, March 1993.

9. D. S. Liscinsky, B. True, and J. D. Holdeman, "An Experimental Study of Crossflow Jet Mixing in Rectangular Ducts," AIAA-93-2037, June 1993 (Also TM 106152).

10. D. B. Bain, C. E. Smith, and J. D. Holdeman, "CFD Mixing Analysis of Axially Opposed Rows of Jets Injected in Confined Crossflow," Journal of Propulsion and Power, Vol. 11, No. 5, p. 885893, September-October 1995 (See also AIAA Paper 93-2044 and NASA TM 106179).

11. D. B. Bain, C. E. Smith, and J. D. Holdeman, "CFD Assessment of Orifice Aspect Ratio and Mass Flow Ratio on Jet Mixing in Rectangular Ducts," AIAA Paper 94-0218, January 1994 (Also NASA TM 106477).

12. D. S. Liscinsky, B. True, and J. D. Holdeman, "Mixing Characteristics of Directly Opposed Rows of Jets Injected Normal to a Crossflow in a Rectangular Ducts," AIAA Paper 94-0217, January 1994 (Also NASA TM 106477).
13. D.S. Liscinsky, B. True, and J.D. Holdeman, "Crossflow Mixing of Noncircular Jets," Journal of Propulsion and Power, Vol. 12, No. 2, pp. 225230, January-February 1996 (See also ALAA Paper 95-0732 and NASA TM 106865).

14. Th. Doerr and D. K. Hennecke, "The Mixing Process in the Quenching Zone of the Rich-Lean Combustion Concept," AGARD 81 st Symposium on Fuels and Combustion Technology for Advanced Aircraft Engines, Colleferro, NR Rome, Italy, May 10-14, 1993.

15. Th. Doerr, M. Blomeyer, and D. K. Henneke, "Optimization of Multiple Jets Mixing with a Confined Crossflow," ASME Paper 95-GT-313, 1995.

16. Th. Doerr, M. Blomeyer, and D. K. Henneke, "Experimental Investigation of Optimum Jet Mixing Configurations for RQL-Combustors," 12th ISABE, Melborne, Aus., 1995.

17. J. F. Carrotte, and S. J. Stevens, "The Influence of Dilution Hole Geometry on Jet Mixing," J. of Engineering for Gas Turbines and Power, Vol. 112 , No. 1, pp. 73-75, January 1990 (See also ASME Paper 89-GT-292).

18. S. J. Stevens, and J. F. Carrotte, "Experimental Studies of Combustor Aerodynamics, Part I: Mean Flowfields," J. of Propulsion and Power, Vol. 6, No. 3, pp. 297-304, May-June 1990 (See also AIAA Paper 87-1827, The Influence of Dilution Hole Aerodynamics on the Temperature Distribution in a Combustor Dilution Zone).

19. S. J. Stevens, and J. F. Carrotte, "Experimental Studies of Combustor Dilution Zone Aerodynamics, Part II: Jet Development," J. of Propulsion and Power, Vol. 6, No. 4, pp. 503511, July-August 1990 (See also AIAA Paper 883274).

20. J. J. McGuirk and S. J. Baker, "Multi-Jet Annulus/ Core-Flow Mixing-Experiments and Calculations," ASME 92-GT-111, 1992.

21. J. J. McGuirk and A. Spencer, "CFD Modeling of Annulus/Port Flows," ASME 93-GT-185, 1993.

22. S. F. Owens, "CFD-ACE: Command Language Reference Manual," CFD Research Corporation, Huntsville, AL, CFDRC Report GR-92-6, 1992.

23. B. E. Launder and D. B. Spalding, "The Numerical Computation of Turbulent Flows," Computer Methods in Applied Mechanics and Engineering, Vol. 3, pp. 269-289, 1974. 
24. Y. S. Chen and S. W. Kim, "Computation of Turbulent Flows Using an Extended $k-\varepsilon$ Turbulence Closure Model," NASA CR-179204, 1987.

25. K. Y. Chien, "Predictions of Channel and Boundary-Layer Flows with a Low-Reynolds Number-Turbulence Model," AIAA Journal, Vol. 23, No. 2, 1985.

26. CFD-GEOM User Manual, Version 1.3, March 1995.

27. P. V. Danckwertz, "The Definition and Measurement of Some Characteristics of Mixtures," Appl. Sci. Res., Sec. A., Vol. 3, pp. 279-296, 1952.

28. S. Lichtarowicz, R. K. Duggins, and E. Markland, "Discharge Coefficients for Incompressible NonCavitating Flow Through Long Orifices," Journal Mechanical Engineering Science, Vol. 7, No. 2, pp. 210-219, 1965. 


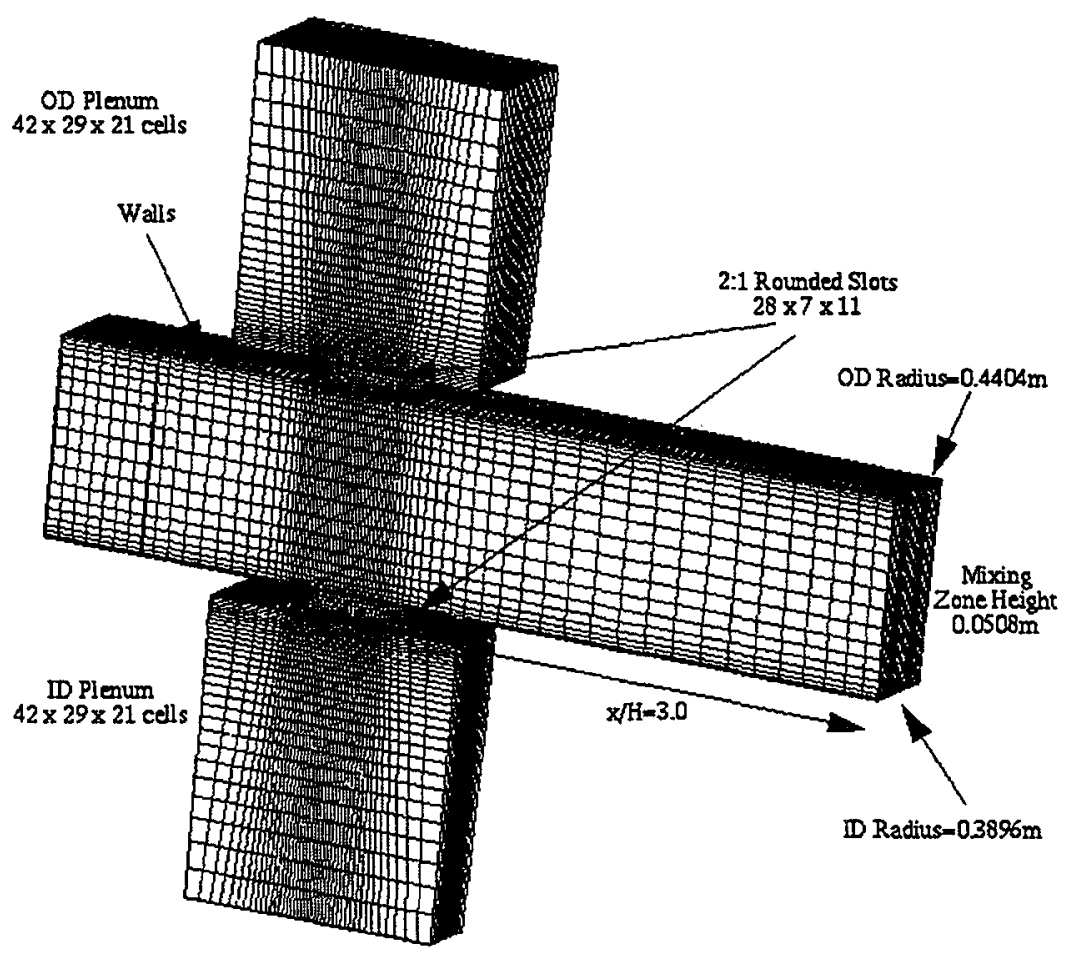

Figure 1. Baseline Annular Geometry and Grid
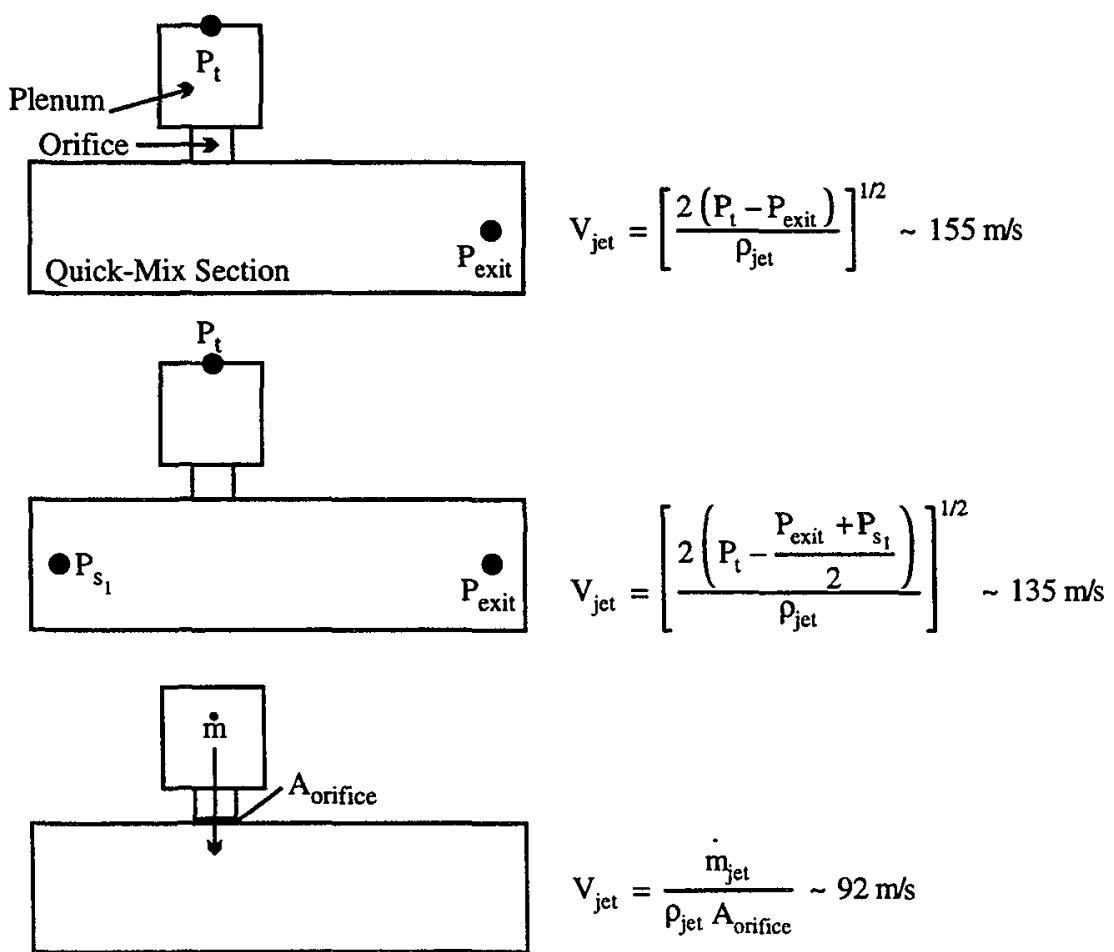

Figure 2. Three Methods Used to Determine Jet Velocity for Combustor-Only Calculations 9

American Institute of Aeronautics and Astronautics 


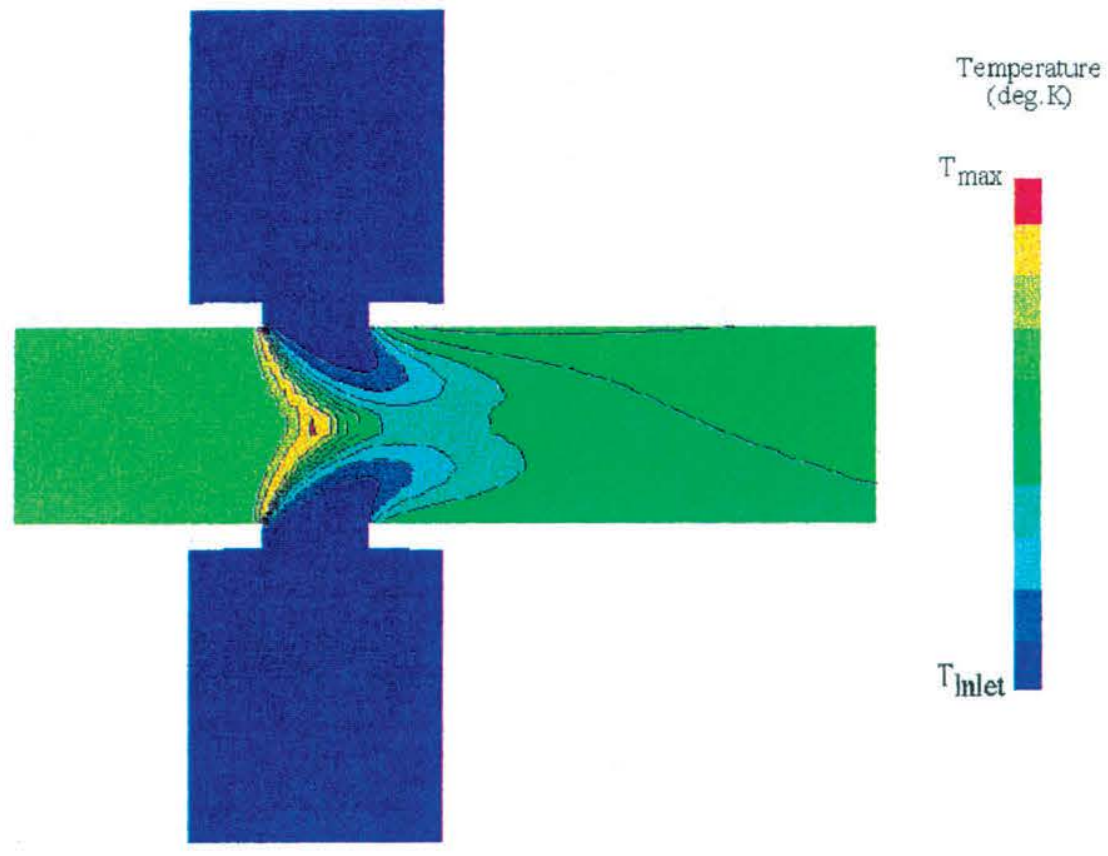

Figure 3. Temperature Contours for Baseline Plenum-Fed Geometry

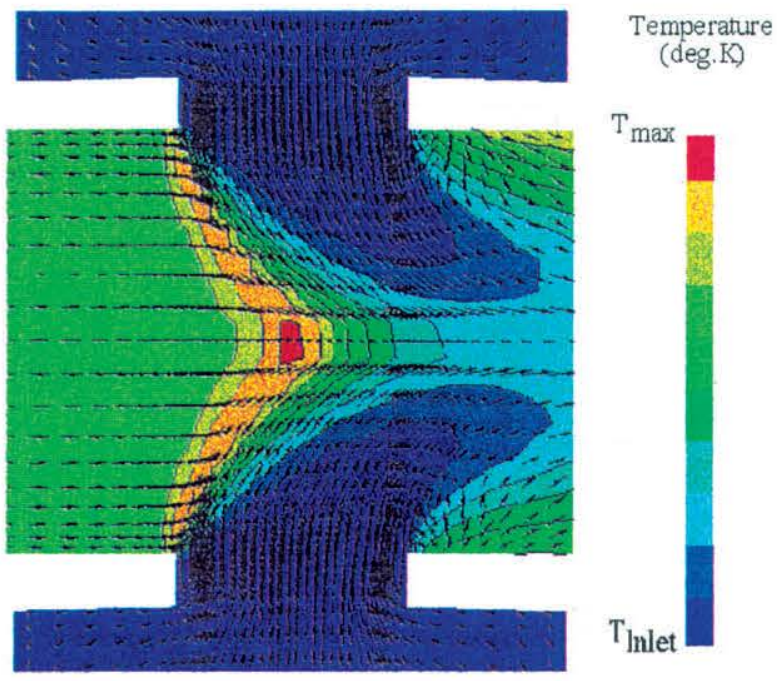

Figure 4. Close-Up of Velocity Flowfield through Thick-Walled Combustor 


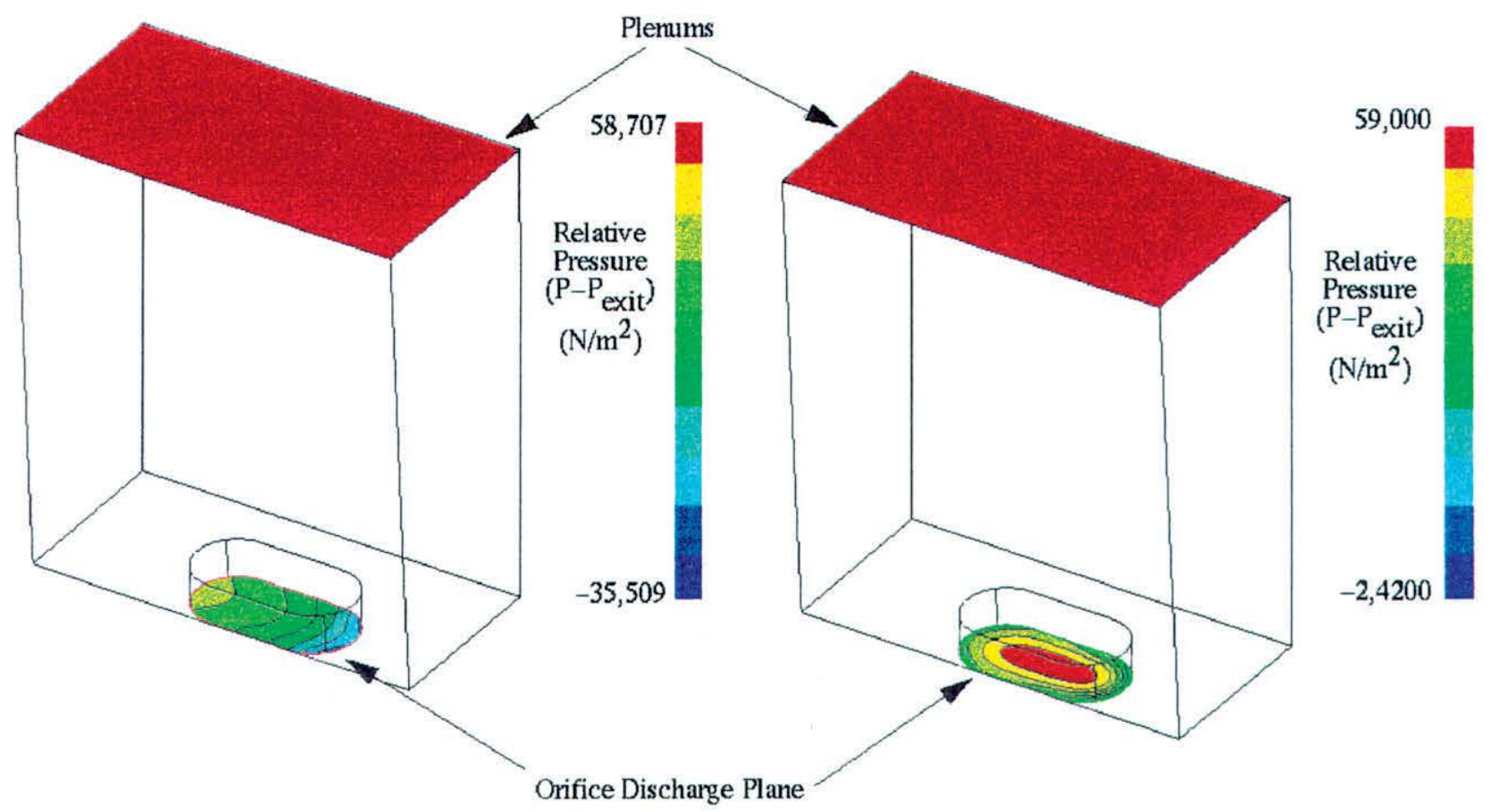

Figure 5. Non-Uniform Static Pressure Distribution Across the Orifice Exit Plane

Figure 6. Non-Uniform Total Pressure Distribution Across the Orifice Exit Plane

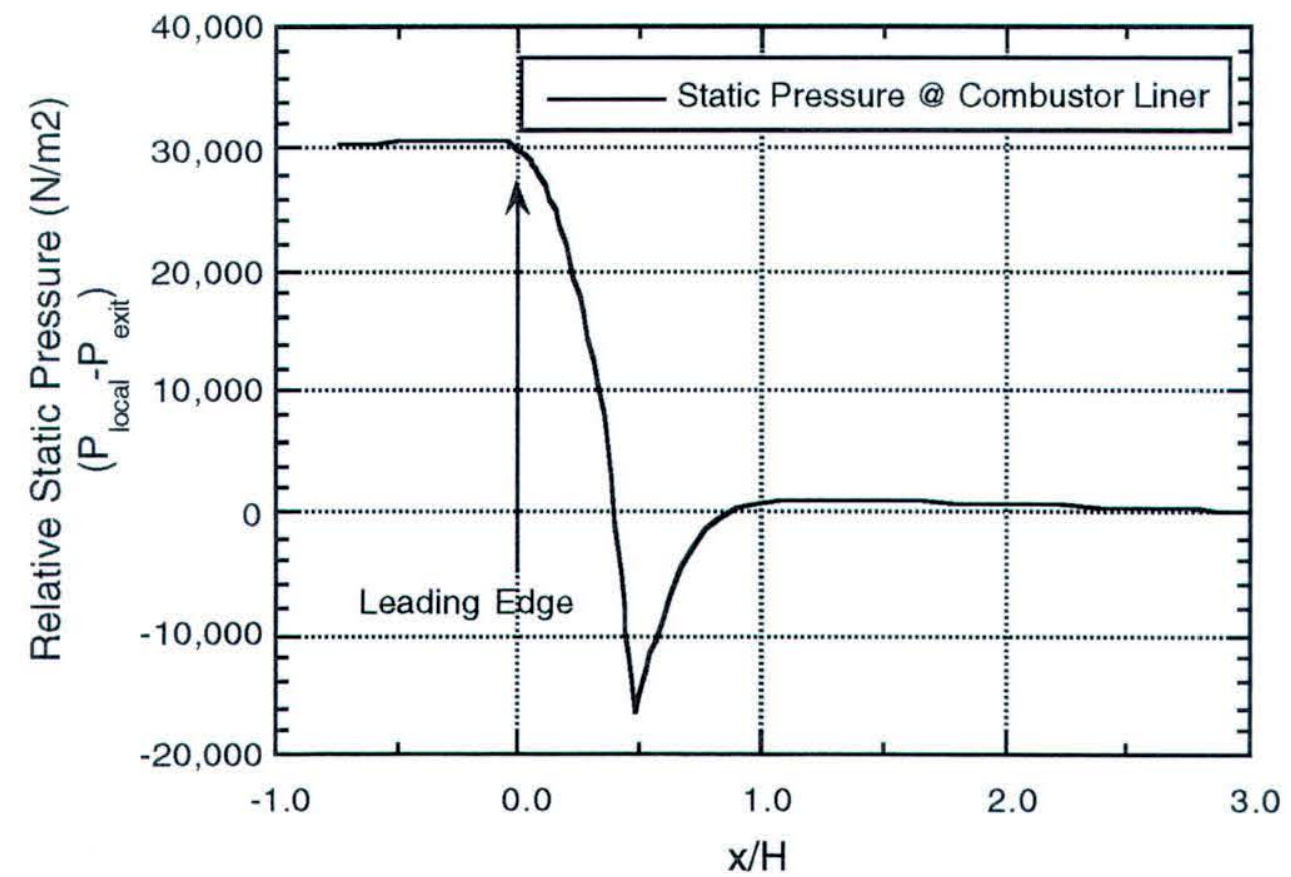

Figure 7. Non-Uniform Static Pressure at Combustor Liner (Orifice extends from $0<\mathrm{x} / \mathrm{H}<0.5$ ) 

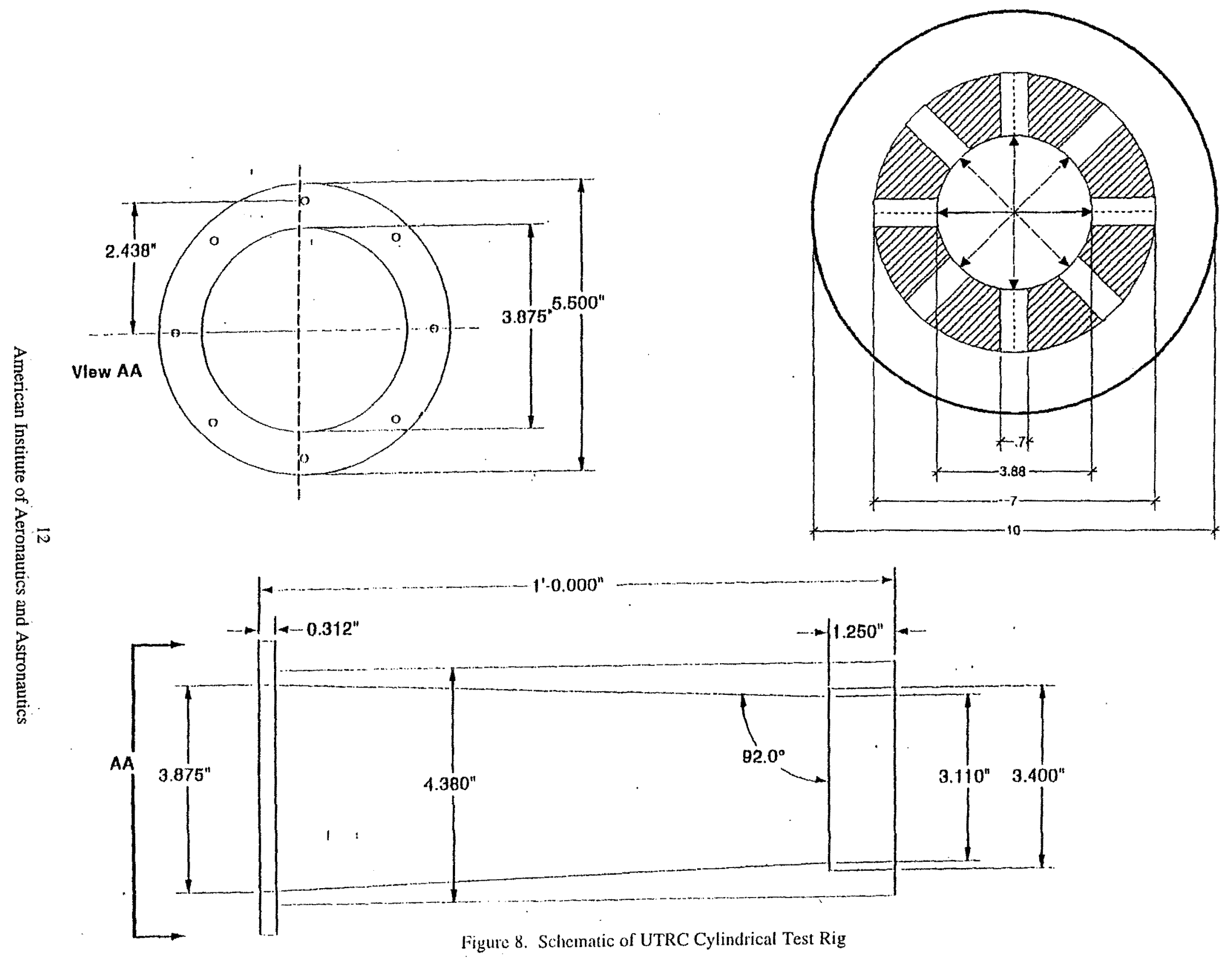


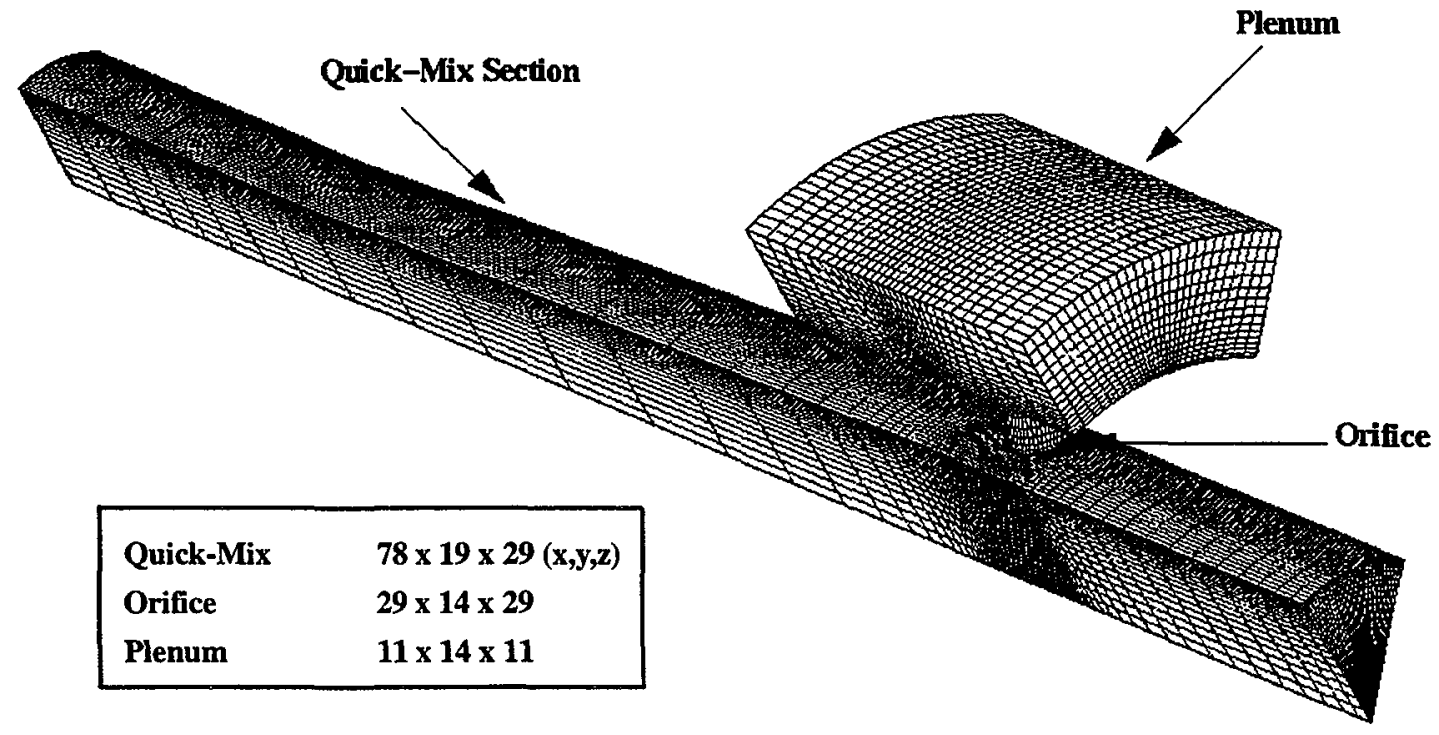

Figure 9. Computational Mesh of UTRC Cylindrical Geometry 

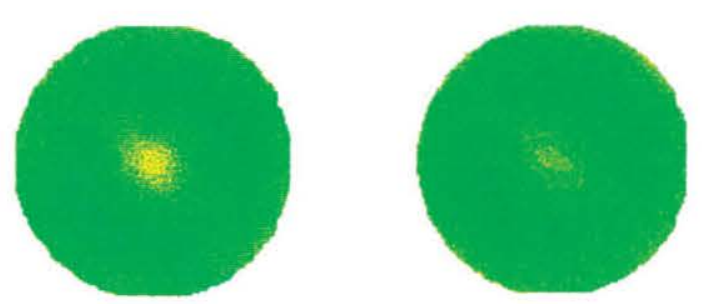

Mixture

Fraction

UTRC Experimental Measurements

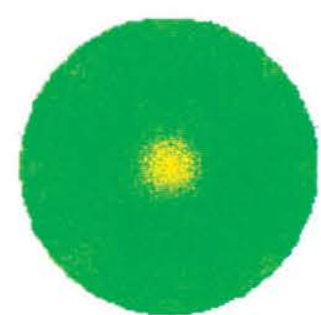

$\mathrm{x} / \mathrm{R}=1.28$

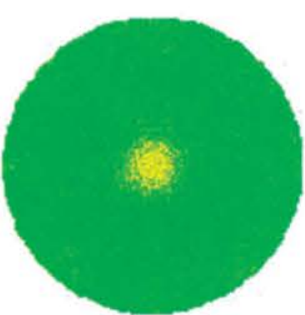

$\mathrm{x} / \mathrm{R}=1.54$

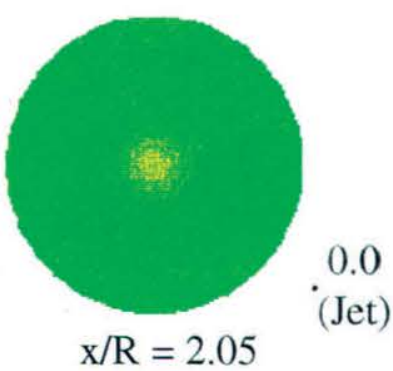

$\mathrm{x} / \mathrm{R}=2.05$
1.0 (Main)

CFD-ACE Computational Predictions

Figure 10. Comparison of CFD-ACE and Experimental Measurements

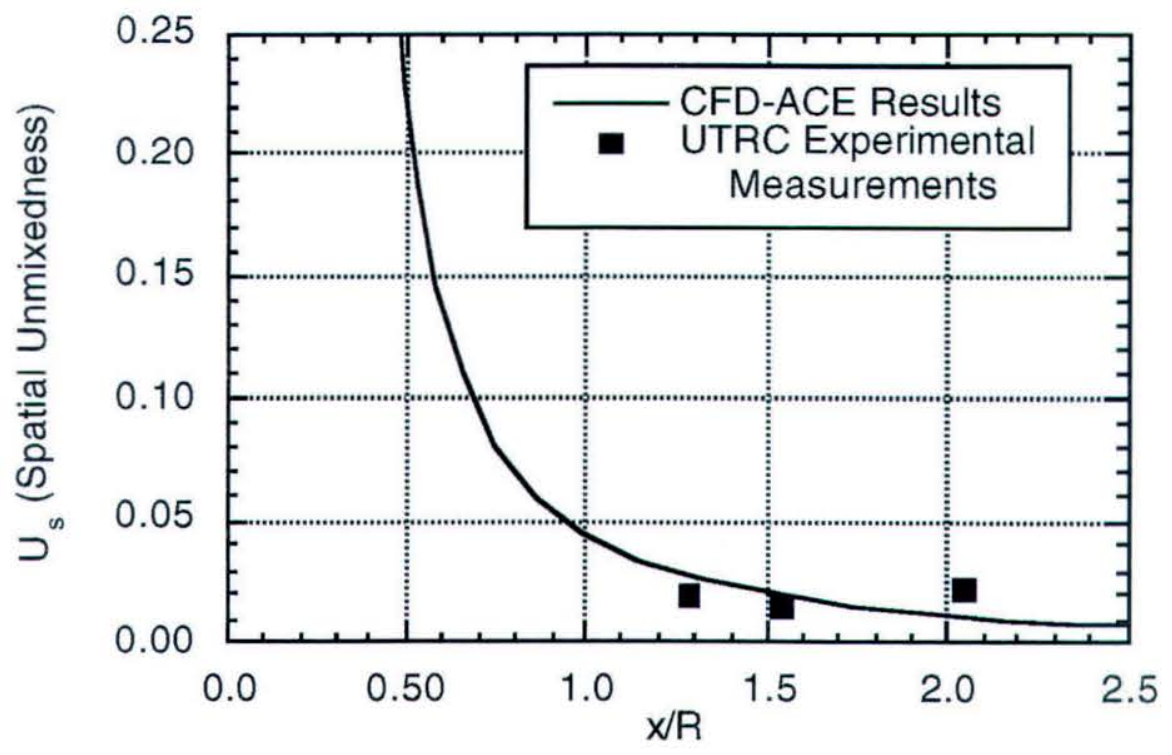

Figure 11. Numerical and Experimental Comparison of Spatial Unmixedness 


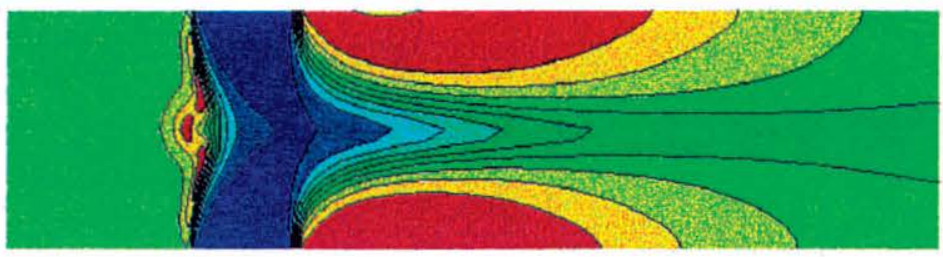

Method1

(Velocity Based on Overall

Combustor Pressure Drop)
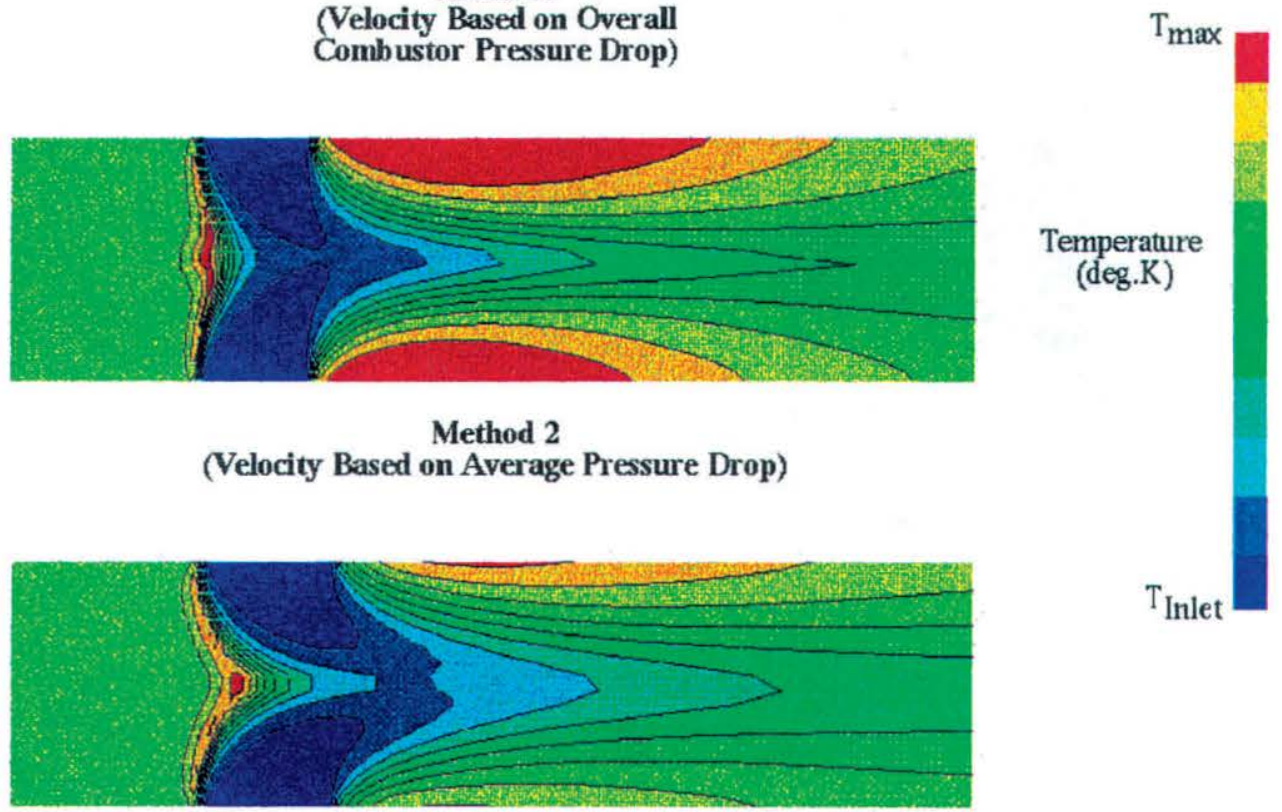

TInlet

Method 2

(Velocity Based on Average Pressure Drop)

\section{Method 3}

(Velocity Based on Flow

Through Geomenic Orifice Area)

Figure 12. Combustor - Only Analysis for 4 Orifices ID \& OD in $15 \mathrm{deg}$. Sector 


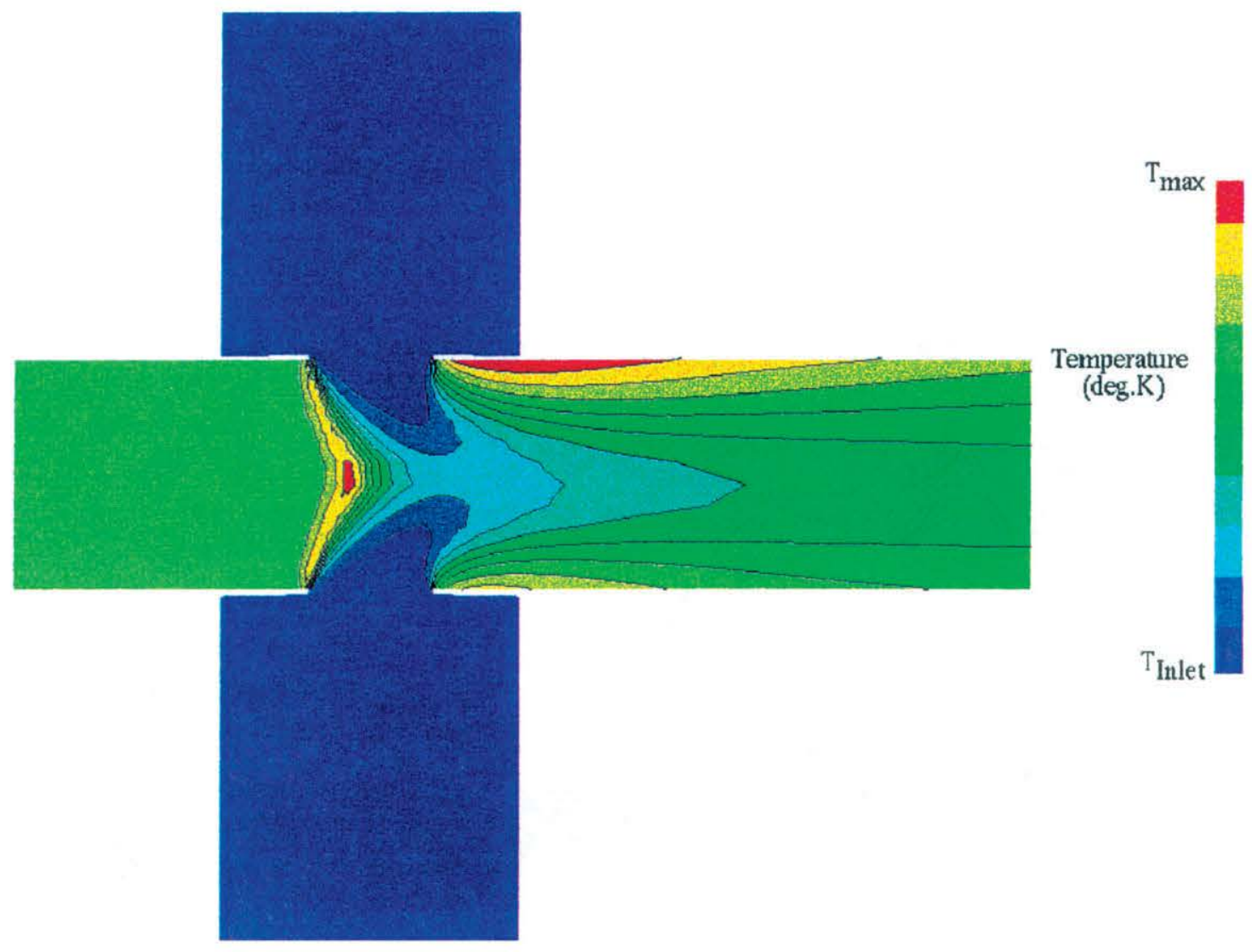

Figure 13. Temperature Contours for the Thin-Walled Geometry
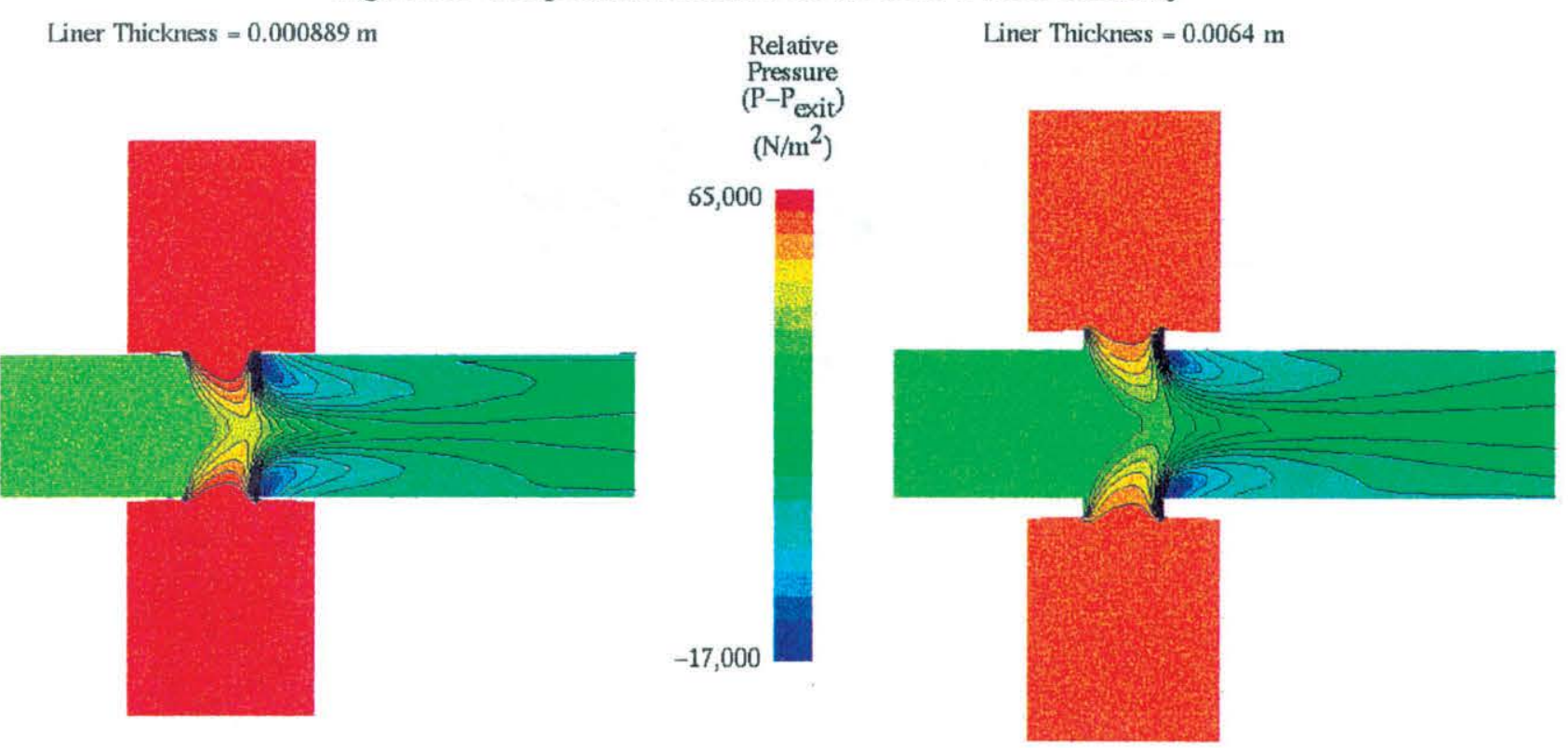

Figure 14. Total Pressure Centerline Slices for Thin and Thick-Walled Geometry

American Institute of Aeronautics and Astronautics 

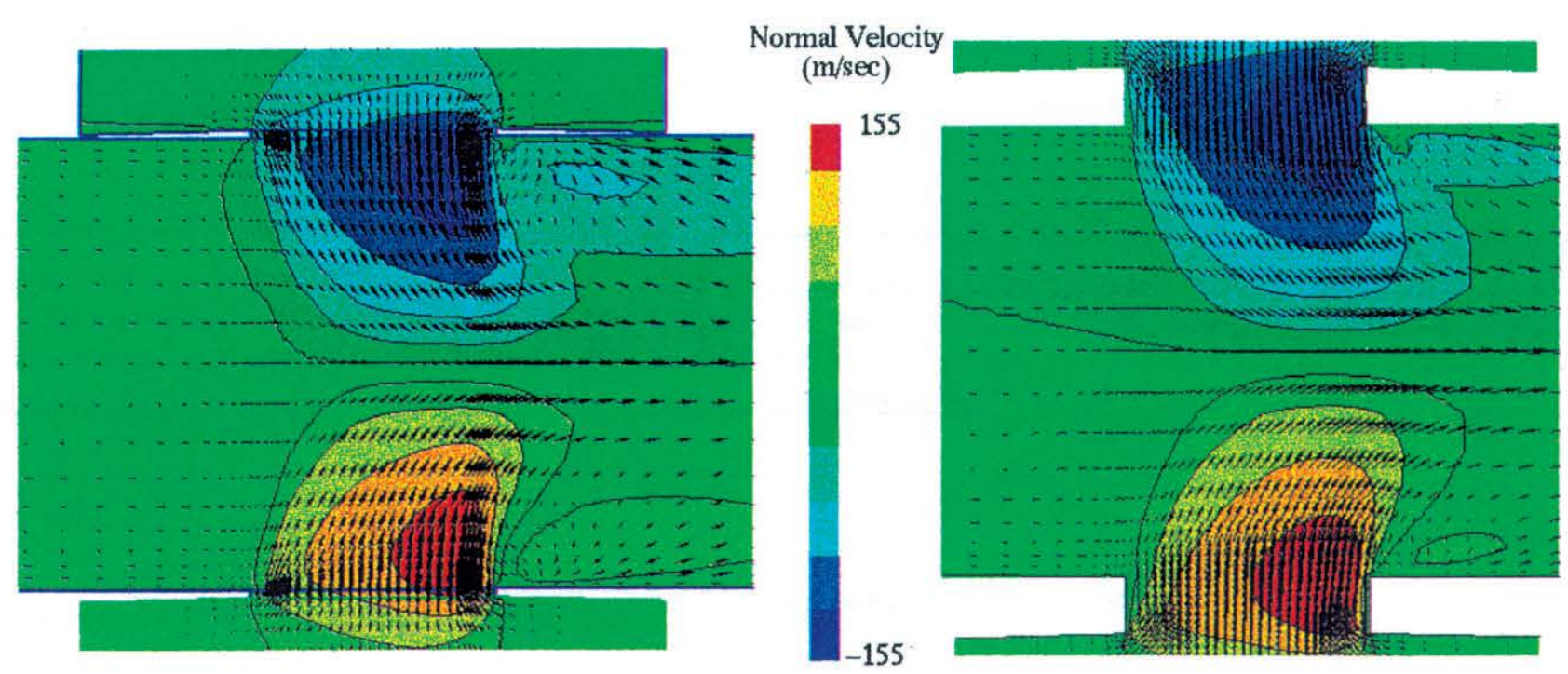

Figure 15. Velocity Profile Comparison Between Thick-Walled and Thin-Walled Combustor 
Public reporting burden for this collection of information is estimated to average 1 hour per response, including the time for reviewing instructions, searching existing data sources, gathering and maintaining the data needed, and completing and reviewing the collection of information. Send comments regarding this burden estimate or any other aspect of this collection of information, including suggestions for reducing this burden, to Washington Headquarters Services, Directorate for Information Operations and Reports, 1215 Jefferson Davis Highway, Suite 1204, Arlington, VA 22202-4302, and to the Office of Management and Budget, Paperwork Reduction Project (0704-0188), Washington, DC 20503.

\begin{tabular}{|l|l|l|}
\hline 1. AGENCY USE ONLY (Leave blank) & $\begin{array}{c}\text { 2. REPORT DATE } \\
\text { June } 1996\end{array}$ & $\begin{array}{r}\text { 3. REPORT TYPE AND DATES COVERED } \\
\text { Technical Memorandum }\end{array}$ \\
\hline
\end{tabular}

\section{TITLE AND SUBTITLE} 5. FUNDING NUMBERS

Flow Coupling Effects in Jet-In-Crossflow Flowfields

6. AUTHOR(S)

WU-537-02-20-00

D.B. Bain, C.E. Smith, D.S. Liscinsky, and J.D. Holdeman

7. PERFORMING ORGANIZATION NAME(S) AND ADDRESS(ES)

National Aeronautics and Space Administration

Lewis Research Center

Cleveland, Ohio 44135-3191

8. PERFORMING ORGANIZATION

REPORT NUMBER

E-10318

9. SPONSORING/MONITORING AGENCY NAME(S) AND ADDRESS(ES)

National Aeronautics and Space Administration

Washington, DC 20546-0001

10. SPONSORING/MONITORING

AGENCY REPORT NUMBER

NASA TM-107257

AIAA-96-2762

\section{SUPPLEMENTARY NOTES}

Prepared for the 32nd Joint Propulsion Conference cosponsored by AIAA, ASME, SAE, and ASEE, Lake Buena Vista, Florida, July 1-3, 1996. D.B. Bain and C.E. Smith, CFD Research Corporation, Huntsville, Alabama 35805;

D.S. Liscinsky, United Technologies Research Center, East Hartford, Connecticut 06108; J.D. Holdeman, NASA Lewis Research Center. Responsible person, J.D. Holdeman, organization code 2650, (216) 433-5846.

12a. DISTRIBUTION/AVAILABILITY STATEMENT

12b. DISTRIBUTION CODE

Unclassified - Unlimited

Subject Category: 07

Available electronically at http://gltrs.grc.nasa.gov/GLTRS

This publication is available from the NASA Center for AeroSpace Information, (301) 621-0390.

13. ABSTRACT (Maximum 200 words)

The combustor designer is typically required to design liner orifices that effectively mix air jets with crossflow effluent. CFD combustor analysis is typically used in the design process; however the jets are usually assumed to enter the combustor with a uniform velocity and turbulence profile. The jet-mainstream flow coupling is usually neglected because of the computational expense. This CFD study was performed to understand the effect of jet-mainstream flow coupling, and to assess the accuracy of jet boundary conditions that are commonly used in combustor internal calculations. A case representative of a plenum-fed quick-mix section of a Rich Burn/Quick Mix/Lean Burn combustor (i.e., a jet-mainstream mass-flow ratio of about 3 and a jet-mainstream momentum-flux ratio of about 30) was investigated. This case showed that the jet velocity entering the combustor was very non-uniform, with a low normal velocity at the leading edge of the orifice and a high normal velocity at the trailing edge of the orifice. Three different combustor-only cases were analyzed with uniform inlet jet profile. None of the cases matched the plenum-fed calculations. To assess liner thickness effects, a thin-walled case was also analyzed. The CFD analysis showed the thin-walled jets had more penetration than the thickwalled jets.

14. SUBJECT TERMS Emissions; Dilution jet mixing; Gas turbine engine; Combustion chamber 15. NUMBER OF PAGES 19

\begin{tabular}{|c|c|}
\hline $\begin{array}{c}\text { 17. SECURITY CLASSIFICATION } \\
\text { OF REPORT } \\
\text { Unclassified }\end{array}$ & $\begin{array}{c}\text { 18. SECURITY CLASSIFICATION } \\
\text { OF THIS PAGE } \\
\text { Unclassified }\end{array}$ \\
\hline
\end{tabular}

19. SECURITY CLASSIFICATION
OF ABSTRACT
Unclassified

Standard Form 298 (Rev. 2-89)

Prescribed by ANSI Std. Z39-18 298-102 